\title{
Conservation unit and water quality: the influence of environmental integrity on benthic macroinvertebrate assemblages
}

Unidade de conservação e qualidade de água: a influência da integridade ambiental sobre assembléias de macroinvertebrados bentônicos

\author{
Jessé Renan Scapini Sobczak ${ }^{1,2}$; Alice Teresa Valduga ${ }^{2}$, \\ Rozane Maria Restello ${ }^{1,2}$ and Rafael Imlau Cardoso ${ }^{1}$
}

${ }^{1}$ Laboratório de Biomonitoramento, Departamento de Ciências Biológicas,

Universidade Regional Integrada do Alto Uruguai e das Missões - URI, Campus de Erechim,

Av. Sete de Setembro, 1621, CEP 99700-000, Erechim, RS, Brazil

e-mail: jesserenan@yahoo.com.br, rrozane@uri.com.br, rafael.i.cardoso@hotmail.com

${ }^{2}$ Programa de Pós-graduação em Ecologia, Universidade Regional Integrada do Alto Uruguai e das Missóes - URI, Campus de Erechim, Av. Sete de Setembro, 1621, CEP 99700-000, Erechim, RS, Brazil e-mail: valice@uri.com.br

\begin{abstract}
Aim: This study aimed to determine the effectiveness of a Conservation Unit (CU) in maintaining the quality of freshwater habitats and to evaluate the influence of environmental integrity on benthic macroinvertebrate assemblages. Methods: The research was conducted at sampling sites located within and outside of the $\mathrm{CU}$ in the Alto Uruguai region, southern Brazil, and included two stages: (i) the collection of benthic macroinvertebrates and (ii) the application of a Rapid Assessment Protocol (RAP) to characterise the habitat quality. Results: A total of 1,362 benthic macroinvertebrates were collected during the study, totalling 30 taxa. The densities within and outside the $\mathrm{CU}$ were significantly different $(\mathrm{F}=160.08 ; \mathrm{p}=0.05)$, and the Shannon diversity and taxa richness followed the same pattern $(\mathrm{F}=118.72, \mathrm{p}=0.05$; and $\mathrm{F}=176.33, \mathrm{p}=0.04$, respectively). In contrast, the Pielou equitability did not differ within and outside the $\mathrm{CU}(\mathrm{F}=0.19$, $\mathrm{p}=0.74$ ). The biotic index (Biological Monitoring Working Party) indicated that water quality was good or very good in the majority of cases. Most of the sampling sites were classified as 'natural' according to the RAP. The taxa richness was significantly related to habitat diversity $(F=7.24 ; \mathrm{p}=0.05)$, but no significant relationship was found between the habitat diversity and the Shannon diversity $(F=2.13, p=0.22)$. Conclusion: The $\mathrm{CU}$ was effective for the conservation of water quality and the freshwater biodiversity of benthic macroinvertebrates. The results show that the environmental integrity was related to the distribution of benthic macroinvertebrates, primarily to the taxa richness. More detailed investigations need to be developed to better understand these relationships and to take into account the temporal scale. An analysis of the most significant sources of stress on the aquatic life outside the area is recommended.
\end{abstract}

Keywords: benthic macroinvertebrates, protected area, habitat diversity, spatial distribution, freshwater ecosystem, Southern Brazil.

Resumo: Objetivo: Este estudo teve como objetivo determinar a eftcácia de uma Unidade de Conservaçáo (UC) em manter a qualidade de hábitats aquáticos e avaliar a influência da integridade ambiental sobre as assembléias de macroinvertebrados bentônicos. Métodos: A pesquisa foi realizada em pontos amostrais localizados dentro e fora de uma UC na regiáo do Alto Uruguai, sul do Brasil, e incluiu duas etapas: (i) a coleta de macroinvertebrados bentônicos e, (ii) a aplicação de um Protocolo de Análise Rápida (PAR) para caracterizar a qualidade de habitat. Resultados: Um total de 1,362 organismos foram coletados durante o estudo, totalizando 30 taxa. As densidades dentro e fora da UC foram significativamente diferente $(F=160.08, p=0.05)$, e a diversidade de Shannon e riqueza de táxons seguiram o mesmo padrão $(\mathrm{F}=118.72$, $\mathrm{p}=0.05$; e $\mathrm{F}=$ 176.33, $\mathrm{p}=0.04$, respectivamente). Em contraste, a equitabilidade de Pielou não diferiu dentro e fora da UC $(\mathrm{F}=0.19, \mathrm{p}=0.74)$. O índice biótico (Biological Monitoring Working Party) indicou que a qualidade da água foi boa ou muito boa na maioria dos casos. A maioria dos pontos amostrais foram classificados como "natural" de acordo com o PAR. A riqueza de táxons foi significativamente relacionada com a diversidade de habitat $(\mathrm{F}=$ 
7.24, $p=0.05)$, mas nenhuma relação significativa foi encontrada entre a diversidade de habitat e a diversidade de Shannon $(F=2.13, p=0.22)$. Conclusáo: A UC foi efetiva para a conservação da qualidade da água e a biodiversidade aquática de macroinvertebrados bentônicos. Os resultados sugerem que a integridade ambiental estava relacionada com a distribuição de macroinvertebrados bentônicos, principalmente com a riqueza de táxons. Investigaçóes mais detalhadas devem ser desenvolvidas para compreender melhor essas relaçôes e levar em conta a escala temporal. Recomenda-se uma análise das mais importantes fontes de estresse à vida aquática fora da área.

Palavras-chave: macroinvertebrados bentônicos, área protegida, diversidade de habitat, distribuição espacial, ecossistema de água doce, Sul do Brasil.

\section{Introduction}

Historically, most protected areas (PAs) have been designated to protect charismatic terrestrial species, outstanding scenic value, or the sources of water supplies for urban and agricultural purposes. These areas provide only incidental protection to freshwater biodiversity (Crivelli, 2002; Dudley and Stolton, 2003; Agostinho et al., 2004; Ibase, 2006; Abell et al., 2007; Medeiros et al., 2011). This situation persists because few models of good designs for PAs exist, and traditional notions of PAs are difficult to apply to the freshwater realm (Abell et al., 2007). Although they remain rare, such areas, including conservation units ${ }^{1}$ (CUs), a particular category of protected area in Brazil, have been established specifically to protect freshwater species and habitats (Saunders et al., 2002), and interest in freshwater conservation has been growing, both in the scientific community and among conservation organisations (Allan and Flecker, 1993; Trout Unlimited, 1993; Moyle and Yoshiyama, 1994; McAllister et al., 1997; Richter et al., 1997; Young, 1997; Master et al., 1998; IUCN, 1999; Braun et al., 2000).

More recently, PAs have been designated based on a broader array of values. However, these PAs often fail to conserve the aquatic features within the areas due to a lack of consideration either of freshwater ecosystem needs in their design and management or of the broader context in which they operate (Thieme et al., 2012). Legally protected status is not sufficient to preserve ecological integrity in most anthropogenically altered areas (White and Bratton, 1980; Lajeunesse et al., 1995). Among the aquatic organisms that have suffered as a result of intense habitat degradation, benthic macroinvertebrate assemblages have been frequently studied due to their importance in the flow of energy and nutrient cycling. The primary input to these processes is allochthonous litter occurring in riparian zones

${ }^{1}$ National System of Conservation Units (NSCU) (2000). in limnic ecosystems (Rosenberg and Resh, 1993, Moretti et al., 2007, Trevisan and Hepp, 2007). These processes result in a longitudinal gradient of organic matter transformation and nutrient sources along an ecological continuum (Vannote et al., 1980; Callisto and Gonçalves, 2002; Giller and Malmqvist, 2008).

The creation of PAs does not automatically result in the improvement of the biological quality of streams, and their size does not play a decisive role in preserving the benthic macroinvertebrate community (Mancini et al., 2005). Development projects that reduce the vegetative cover of riparian zones have several impacts on streams (Naiman et al., 1993; Calow and Petts, 1994; Ataroff and Rada, 2000; Neill et al., 2001). For example, dam building or the diversion of water for agriculture can occur outside park boundaries and still have negative consequences for freshwater habitats within the park (Saunders et al., 2002). As a result of these factors, the causes of and solutions for the pollution of water resources are not found directly within the water body itself (Pereira-Silva et al., 2011). The search for causes and solutions of water pollution should consider entire river basins and should integrate other environmental resources and analyses of the environmental structure (Moulton and Souza, 2006)

In this context, the application of rapid evaluation techniques has attracted interest. Rapid evaluation techniques are usually used in biomonitoring programmes because they offer simplicity, low cost, and decreased sampling efforts (Buss, 2008). Many researchers support the application of these protocols (Plafkin et al., 1989; Resh, 1995; Silveira et al., 2005). This approach focuses on the use of benthic macroinvertebrates and rapid evaluation techniques to supply accurate information for use in pollution research. The present study aims to evaluate the effectiveness of a $\mathrm{CU}$ for the maintenance of the quality of freshwater 
habitats and the influence of environmental integrity on benthic macroinvertebrate assemblages.

\section{Material and Methods}

\subsection{Study area}

This study was conducted in October 2009 in the Mata do Rio Uruguai Teixeira Soares Municipal Natural Park (PTS), located in Marcelino Ramos city, situated in the northern region of Rio Grande do Sul state (Southern Brazil). The area covered by the park is 429,65 ha. The annual average precipitation in the area is $1,708 \mathrm{~mm}$ (Restello and Penteado-Dias, 2006). The PTS is the first area to be protected for its biodiversity in the Alto Uruguai region and is one of the noteworthy remaining fragments of the Latifoliada subtropical forest (Rampazzo et al., 2000) (Figure 1).

The study consisted of two stages. First, the benthic macroinvertebrates were collected, and during the second stage, a Rapid Assessment Protocol (RAP) was applied to characterise the environmental integrity (habitat quality) according to Callisto et al. (2002). The benthic macroinvertebrates were sampled from stone substrates with a Surber sampler $\left(\right.$ mesh $=250 \mathrm{~mm}$; area $\left.=0.1 \mathrm{~m}^{2}\right)$ at six sampling sites, with two pseudo-replicates at each site, in second- and third-order streams. Sampling sites p1, p3, and p5 were located inside the PTS, and sampling sites $\mathrm{p} 2, \mathrm{p} 4$, and $\mathrm{p} 6$ were located in the surrounding areas (Table 1).

The collected biological material was fixed in situ with $80 \%$ alcohol, taken to the laboratory, and washed in sieves to remove the organisms. The organisms were identified at the lowest possible taxonomic level using the identification guidelines of Merritt and Cummins (1996), Fernandez and Domingues (2001), and Costa et al. (2006). According to Melo (2005) and Corbi and TrivinhoStrixino (2006), family-level identifications of benthic macroinvertebrates for biomonitoring purposes do not compromise the results. The identified material was deposited in the Collection of Benthic Invertebrates at the Museum of Alto Uruguai, Universidade Regional Integrada do Alto Uruguai e das Missôes (URI).

\subsection{Data analysis}

To analyse the structure of benthic macroinvertebrate assemblages, the density (ind. $\mathrm{m}^{-2}$ ), taxa richness, Shannon diversity, and Pielou evenness were calculated (Magurran, 2004). A two-way analysis of variance (ANOVA) was used to evaluate the differences in the structure within and outside of the PTS using the parameters previously cited.

A linear regression analysis was used to characterise the influence of habitat diversity (RAP) on taxa richness and Shannon diversity (Gotelli and Ellison, 2004). Water quality was evaluated using

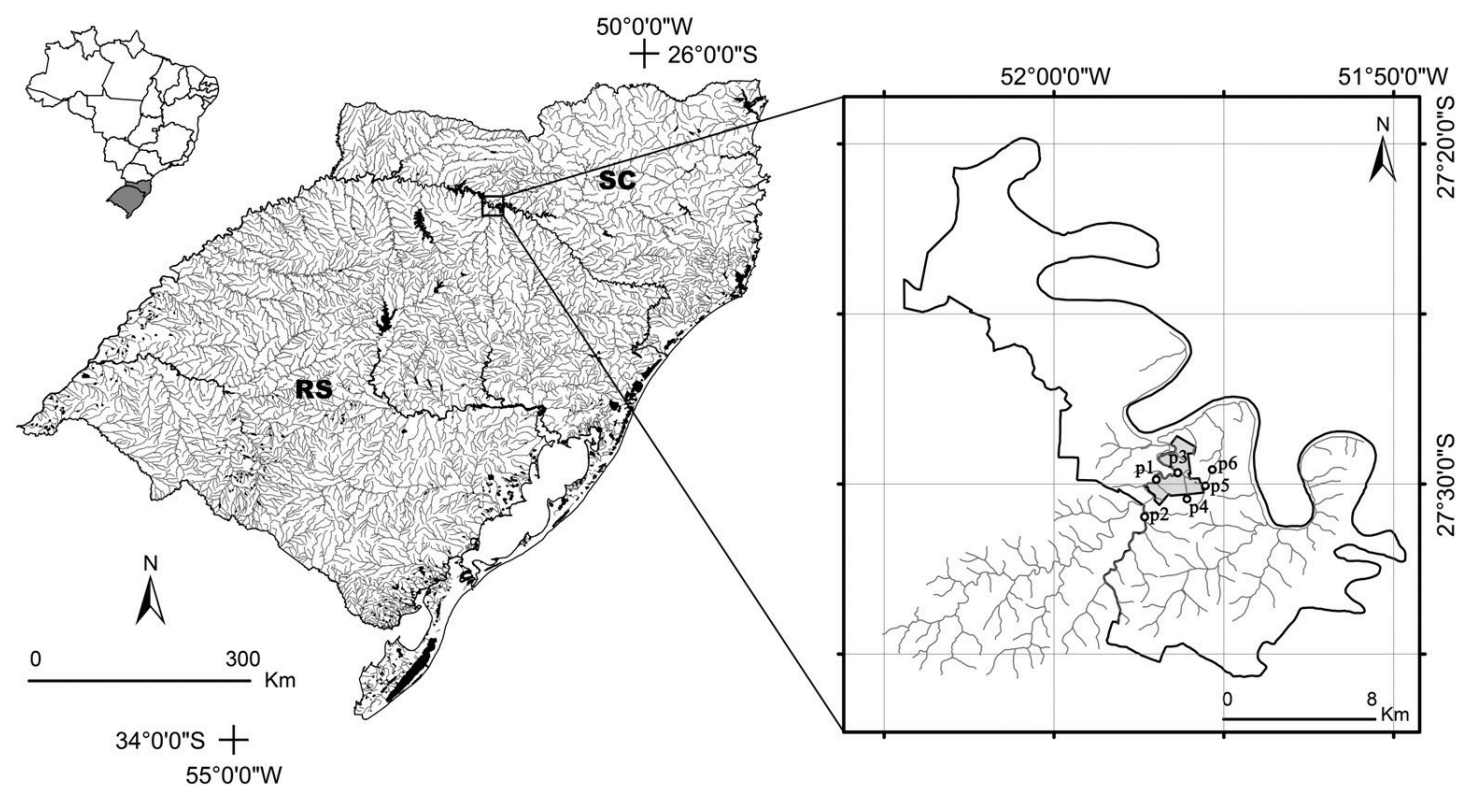

Figure 1. Locations and distribution of the sampling sites within and outside the Mata do Rio Uruguai Teixeira Soares Municipal Natural Park (PTS), situated in the northern region of the state of Rio Grande Do Sul, Marcelino Ramos, 2009 (Southern Brazil). 
Table 1. Characterisation of the sampling sites located inside and outside of the Mata do Rio Uruguai Teixeira Soares Municipal Natural Park, 2009.

\begin{tabular}{cccccc}
\hline Pontos & \multicolumn{2}{c}{ Lat./long } & Altitude* $^{*}$ & Width $^{*}$ & Depth* $^{*}$ \\
\hline p1 & $-27^{\circ} 29^{\prime} 54.4^{\prime \prime}$ & $-51^{\circ} 57^{\prime}$ 00.9" & 398 & 4 & 0.07 \\
p2 & $-27^{\circ} 30^{\prime} 32.4^{\prime \prime}$ & $-51^{\circ} 57^{\prime} 17.4^{\prime \prime}$ & 414 & 3.5 & 0.08 \\
p3 & $-27^{\circ} 29^{\prime} 42.3^{\prime \prime}$ & $-51^{\circ} 56^{\prime} 22.8^{\prime \prime}$ & 392 & 1.5 & 0.05 \\
p4 & $-27^{\circ} 30^{\prime} 36.7^{\prime \prime}$ & $-51^{\circ} 56^{\prime} 16.1^{\prime \prime}$ & 619 & 0.9 & 0.09 \\
p5 & $-27^{\circ} 30^{\prime} 05.6^{\prime \prime}$ & $-51^{\circ} 55^{\prime} 34.6^{\prime \prime}$ & 621 & 2 & 0.11 \\
p6 & $-27^{\circ} 29^{\prime} 36.4^{\prime \prime}$ & $-51^{\circ} 55^{\prime} 21.9^{\prime \prime}$ & 431 & 2.2 & 0.13 \\
\hline
\end{tabular}

${ }^{*}$ Values in meters.

a biotic index (Biological Monitoring Working Party - BMWP) (Mandaville, 2002). All analyses were performed with the $\mathrm{R}$ statistical programme (R Development Core Team, 2009).

\section{Results}

\subsection{Benthic macroinvertebrate assemblages and environmental integrity}

A total of 1,362 benthic macroinvertebrates were collected during the study, totalling 30 taxa. The densities within and outside the PTS were significantly different $(\mathrm{F}=160.08, \mathrm{p}=0.05)$, and the Shannon diversity and taxa richness followed the same pattern $(\mathrm{F}=118.72, \mathrm{p}=0.05$; and $\mathrm{F}=$ 176.33, $\mathrm{p}=0.04$, respectively). In contrast, the Pielou evenness did not differ $(\mathrm{F}=0.19, \mathrm{p}=0.74)$.

The water quality varied from "moderate" to "very good", with "good" quality found at most sampling sites. The habitat diversity was classified as "natural" at all sampling sites with the exception of p6. A significant relationship was identified between the taxa richness and environmental integrity (RAP) $(\mathrm{F}=7.24, \mathrm{p}=0.05)$, with the opposite was observed for the Shannon diversity $(\mathrm{F}=2.13, \mathrm{p}=0.22)$ (Table 2).

\section{Discussion}

\subsection{Benthic macroinvertebrate assemblages and environmental integrity}

Significant differences in the structural attributes of benthic macroinvertebrate assemblages were found within and outside the PTS. Many studies developed in protected areas associate the results with the environmental integrity found (Fricová et al., 2007; Paz et al., 2008; Roux et al., 2008). Decreases in these habitat characteristics can produce a decrease in the number of individuals, affecting the structure and composition of the resident biological communities (Kay et al., 1999; Stenert et al., 2002).
The RAP confirmed that the habitat diversity at the majority of sampling sites was classified as "natural" because the characteristics of these sites showed a high level of environmental integrity. Sampling site $\mathrm{p} 6$ was the sole exception (Table 1). This sampling site is located outside of the PTS in an agricultural matrix, which contributes to its low punctuation. The instrument used for the assessment was satisfactory for the present study. However, it was originally designed for use in the central region of Brazil, and the characteristics of the Alto Uruguai region differ from those found in the central region.

These differences may influence the classification of the sampling sites, and the instrument may require adaptations for the Alto Uruguai region. Modifications are currently being discussed and implemented at various centres for research in Brazil and in the laboratory at URI. For the present study, although the structural attributes were correlated with the environmental integrity (taxa richness and Shannon diversity), only the taxa richness correlation was significant.

In accordance with Flotemersch et al. (2011), the taxa number collected at a given site will increase with sampling effort but will also vary with the biogeography, behaviour, and abundance of the species being sampled and the patchiness of the macrohabitat types. The decrease in habitat diversity causes a decrease in benthic macroinvertebrate richness (Armitage and Petts, 1992; Manel et al., 2000; Walsh et al., 2001; Muotka et al., 2002).

Researchs conducted in Brazil (Rio Grande do Sul state) showed greater taxa richness in different regions (Bueno et al., 2003; Pereira and Luca, 2003; Buckup et al., 2007; Milesi et al., 2009; Biasi et al., 2010). As shown by Bueno et al. (2003), high richness is correlated with good environmental integrity. This association suggests that the availability of habitats, food sources, and niches for occupation is adequate to support the survival of organisms.

The estimates and inferences regarding assemblage attributes (e.g., species richness, 
Table 2. Total density $\left(\mathrm{N}\right.$, ind. $\left.\mathrm{m}^{-2}\right)$, richness of taxa (S, number of taxa), Shannon diversity $(\mathrm{H})$, and Pielou evenness (J) of the benthic macroinvertebrate assemblages. Biotic index (Biological Monitoring Working Party - BMWP) and Rapid Assessment Protocol (RAP) applied in sampling sites located within and outside the Mata do Rio Uruguai Teixeira Soares Municipal Natural Park, Marcelino Ramos, 2009.

\begin{tabular}{|c|c|c|c|c|c|c|c|}
\hline & & p1 & p2 & p3 & p4 & p5 & p6 \\
\hline Nematoda & Oligochaeta & 1 & 0 & 0 & 0 & 0 & 0 \\
\hline Mollusca & Gastropoda & 10 & 9 & 0 & 0 & 1 & 0 \\
\hline Crustacea & Aeglidae & 0 & 0 & 0 & 0 & 1 & 0 \\
\hline Arachnida & Acarina & 0 & 1 & 0 & 0 & 0 & 0 \\
\hline \multirow[t]{4}{*}{ Coleoptera } & Elmidae & 36 & 21 & 5 & 1 & 7 & 9 \\
\hline & Hydrophilidae & 0 & 1 & 0 & 0 & 0 & 0 \\
\hline & Psephenidae & 3 & 1 & 2 & 5 & 10 & 0 \\
\hline & Haliplidae & 0 & 0 & 0 & 1 & 0 & 0 \\
\hline \multirow[t]{6}{*}{ Diptera } & Ceratopogonidae & 0 & 0 & 0 & 2 & 0 & 0 \\
\hline & Chironomidae & 113 & 157 & 50 & 67 & 72 & 211 \\
\hline & Empididae & 0 & 1 & 0 & 0 & 0 & 1 \\
\hline & Simuliidae & 65 & 3 & 9 & 1 & 6 & 74 \\
\hline & Tipulidae & 2 & 0 & 0 & 0 & 0 & 0 \\
\hline & Culicidae & 0 & 2 & 0 & 0 & 0 & 0 \\
\hline \multirow[t]{3}{*}{ Ephemeroptera } & Baetidae & 55 & 30 & 28 & 17 & 12 & 28 \\
\hline & Caenidae & 1 & 13 & 2 & 5 & 4 & 5 \\
\hline & Leptophlebiidae & 17 & 56 & 8 & 12 & 8 & 11 \\
\hline \multirow[t]{4}{*}{ Hemiptera } & Aphididae & 0 & 0 & 1 & 0 & 0 & 0 \\
\hline & Hydrometridae & 0 & 0 & 0 & 0 & 1 & 0 \\
\hline & Lygaeidae & 0 & 0 & 0 & 0 & 2 & 0 \\
\hline & Macroveliidae & 0 & 0 & 0 & 0 & 0 & 1 \\
\hline Lepidoptera & Pyralidae & 0 & 1 & 0 & 0 & 0 & 0 \\
\hline \multirow[t]{2}{*}{ Odonata } & Coenagrionidae & 5 & 1 & 0 & 0 & 4 & 0 \\
\hline & Gomphidae & 1 & 0 & 0 & 0 & 0 & 0 \\
\hline \multirow[t]{2}{*}{ Plecoptera } & Gripopterygidae & 0 & 0 & 1 & 0 & 0 & 1 \\
\hline & Perlidae & 1 & 4 & 1 & 0 & 0 & 5 \\
\hline \multirow[t]{4}{*}{ Trichoptera } & Hydropsychidae & 11 & 3 & 5 & 0 & 4 & 27 \\
\hline & Philopotamidae & 2 & 1 & 0 & 0 & 1 & 0 \\
\hline & Glossosomatidae & 1 & 2 & 0 & 0 & 0 & 0 \\
\hline & Polycentropodidae & 0 & 1 & 0 & 0 & 0 & 1 \\
\hline $\mathbf{N}$ & & 162 & 56 & 154 & 55.5 & 66.5 & 187 \\
\hline $\mathbf{s}$ & & 16 & 11 & 19 & 9 & 14 & 12 \\
\hline H & & 1.871 & 1.645 & 1.661 & 1.31 & 1.734 & 1.399 \\
\hline J & & 0.675 & 0.686 & 0.564 & 0.597 & 0.657 & 0.563 \\
\hline BMWP & & Very good & Good & Very good & Moderate & Good & Good \\
\hline RAP & & Natural & Natural & Natural & Natural & Natural & Modified \\
\hline
\end{tabular}

multimetric index scores) are sensitive to site-scale design and sampling effort because riverine habitats are heterogeneous, with non-uniform distributions of organisms among habitat types (Angermeier and Smogor, 1995; Kanno et al., 2009). The evaluation approach based on diversity indexes is supported because an undisturbed environment will be characterised by high diversity or richness and a homogeneous distribution of individuals over species (high equitability) (Silveira, 2004), according to the water bodies evaluated.

The habitat diversity has been hypothesised to reflect the diversity of organisms (Baptista et al., 2001); however, our results do not support this claim
(Shannon diversity vs RAP). Other determinants, such as the internal characteristics of the river, can affect the potential of the aquatic community, including habitat diversity (Logan and Brooker, 1983; Aadland, 1993). In contrast, the results showed that the taxa richness was significantly related to habitat diversity. These results showed that habitat diversity decreases as a result of human actions, such as the removal of riparian forest, the construction of roads and houses, channelisation, and (in certain cases) impoundment.

Ultimately, effective conservation requires that human interactions be balanced with the natural environment over the long term to ensure 
that human needs continue to be met while simultaneously ensuring that the environment continues to provide the goods and services demanded by society (Skelton, 2002). Conservation efforts for freshwater habitats and species must be based on whole-catchment management (Saunders et al., 2002). If improper use of land and natural resources continues outside protected areas, the future of the CUs will be threatened (Bensusan, 2006). Roux et al. (2008) suggested that people will only support conservation efforts if they are fully aware of the relevant biodiversity issues and their implications and also have the capacity and responsibility to take effective and timely action.

Moreover, the assignment of function to water bodies according to the official boundaries between a $\mathrm{CU}$ and its immediate surroundings is environmentally inefficient, does not contribute to the preservation and restoration of the diversity of natural ecosystems diversity, and fails to protect or recover water (Pereira-Silva et al., 2011). A zoning system is needed for the PTS that is guaranteed by the NSCU, but this was not considered in the original management plan developed by Socioambiental (2001), an environmental consultancy.

The protected area should be augmented by including areas in the vicinity of $\mathrm{p} 2, \mathrm{p} 4$, and $\mathrm{p} 6$. These unprotected sites are included in a recovery zone, which would be protected by a buffer zone. In addition, the water sources should all be connected to the boundaries of the PTS in an effort to properly maintain the health of the watershed through the full protection afforded by this CU. The use of biological variables to monitor the water quality of the PTS is of interest (Buss et al., 2003; Melo, 2003; Silveira, 2004).

\section{Conclusions}

The benthic macroinvertebrate structure differed within and outside the PTS, and the influences of the environmental integrity were partially confirmed, with only taxa richness having a significant positive correlation. This could be related to the period analysed and the fact that this was a single-sample study. More detailed investigations need to be developed to better understand these relationships and to take into account the temporal scale. The sampling efforts at the site-scale level could be extended to other diverse habitat types. Temporal variability is usually the factor that satisfactorily explains these changes, and studies conducted in similar regions have shown that the periodicity of sampling could be addressed by harvesting two times a year.

Furthermore, both instruments used (RAP and BMWP) were very useful. However, an analysis of the most severe sources of stress to aquatic organisms outside the CU, such as the potential utilisation of agricultural defensives, is currently recommended. These sources of stress could not be observed with the present instrument. In addition, the water sources should all be connected to the boundaries of the PTS in an effort to properly maintain the health of the watershed through the full protection afforded by this CU.

In general, the protected area studied can be considered effective for the maintenance of water quality and freshwater biodiversity conservation in terms of benthic macroinvertebrate assemblages. In contrast, a zoning system is needed for the PTS; this is even guaranteed by the NSCU but was not considered in the original management plan developed by Socioambiental. These unprotected sites are included in a recovery zone, which would be protected by a buffer zone, making it possible to prioritise resources to include large portions of the catchments in their freshwater ecosystems.

\section{Acknowledgments}

We thank the two anonymous referees for their useful comments on an early version of this manuscript. My special thanks to Raquel Fetter and Laboratory of Applied Ecology (UnB) in provide data to preparing the map (Figure 1). The first author also acknowledges to Alex Braz Iacone Santos (UFRRJ) for the elaboration of the final map and, Cristiane Biasi (UFSM) by providing support for field work. The english revision was made by American Journal Experts (certificate verification key 0E8C-6A2B-C515-982B-329B).

\section{References}

AADLAND, LP. 1993. Stream habitat types: their fish assemblages and relationship to flow. North American Journal of Fisheries Management, vol. 13, p. 790-806. http://dx.doi.org/10.1577/15488675(1993)013<0790:SHTTFA > 2.3.CO;2

ABELL, R., ALLANB, JD. and LEHNERA, B. 2007. Unlocking the potential of protected areas for freshwaters. Biological Conservation, vol. 134, p. 4863. http://dx.doi.org/10.1016/j.biocon.2006.08.017

AGOSTINHO, AA., THOMAZ, SM. and GOMES, LC. 2004. Threats for biodiversity in the floodplain of the Upper Paraná River; effects of hydrological regulation by dams. Ecohydrology and Hydrobiology, vol. 4 , no. 3, p. 255-268. 
ALLAN, JD. and FLECKER, AS. 1993. Biodiversity conservation in run- ning waters: identifying the major factors that threaten destruction of riverine species and ecosystems. BioScience, vol. 43, p. 33-43.

ANGERMEIER, PL. and SMOGOR, RA. 1995. Estimating number of species and relative abundances in stream-fish communities: effects of sampling effort and discontinuous spatial distributions. Canadian Journal of Fisheries and Aquatic Sciences, vol. 52, p. 936-949. http://dx.doi.org/10.1139/f95-093

ARMITAGE, PD. and PETTS, GE. 1992. Biotic score and prediction to assess the effects of water abstractions on river macroinvertebrates for conservation purposes. Aquatic Conservation: Marine and Freshwater Ecosystems, vol. 2, p. 1-17. http:// dx.doi.org/10.1002/aqc.3270020102

ATAROFF, V. and RADA, EF. 2000. Deforestation impact on water dynamics in a Venezuelan Andean cloud forest. Ambio, vol. 29, p. 440-444.

BAPTISTA, DF., BUSS, DF., DORVILLÉ, LFM. and NESSIMIAN, JL. 2001. Diversity and habitat preference of aquatic insects along the longitudinal gradient of the Macaé river Basin, Rio de Janeiro, Brazil. Revista Brasileira de Biologia, vol. 61, no. 2, p. 249-258.

BENSUSAN, N. 2006. Conservação da Biodiversidade em áreas protegidas. Rio de Janeiro: Editora FGV. 176 p.

BIASI, C., KÖNIG, R. MENDES, V., TONIN, AM., SENSOLO, D., SOBCZAK, JRS., CARDOSO, R., MILESI, SV., RESTELLO, RM. and HEPP, LU. 2010. Biomonitoramento das águas pelo uso de macroinvertebrados bentônicos: oito anos de estudos em riachos da região do Alto Uruguai (RS). Perspectiva, vol. 34, no. 125, p. 67-77.

BRAUN, DP., BACH, LB., CIRUNA, KA, and WARNER, AT. 2000. Watershed-scale abatement of threats to freshwater biodiversity: the Nature Conservancy's freshwater initiative. Vancouver: Proceedings of the Water Environment Federation.

BUCKUP, L., BUENO, AAP., BOND-BUCKUP, G., CASAGRANDE, M. and MAJOLO, F. 2007. The benthic macroinvertebrate fauna of highland streams in southern Brazil: composition, diversity and structure. Revista Brasileira de Zoologia, vol. 24, no. 2, p. 294-301. http://dx.doi.org/10.1590/S010181752007000200005

BUENO, PPA., BOND-BUCKUP, G. and FERREIRA, PDB. 2003. Estrutura da comunidade de invertebrados bentônicos em dois cursos d'água do Rio Grande do Sul, Brasil. Revista Brasileira de Zoologia, vol. 20, p. 115-125. http://dx.doi. org/10.1590/S0101-81752003000100014

BUSS, DF., BAPTISTA, DF. and NESSIMIAN, JL. 2003. Bases conceituais para a aplicaçáo de biomonitoramento em programas de avaliação da qualidade da água de rios. Cadernos de Saúde Pública, vol. 19, no. 2, p. 465-473. PMid:12764462. http:// dx.doi.org/10.1590/S0102-311X2003000200013

BUSS, DF. 2008. Desenvolvimento de um índice biológico para use de voluntários na avaliação da qualidade da água de rios. Oecologia Brasiliensis, vol. 12, p. 516-526.

CALLISTO, M. and GONCALVES, J. 2002. A vida nas águas das montanhas. Ciência Hoje, vol. 31, no. 182 , p. 68-71.

CALLISTO, M., FERREIRA, WR., MORENO, P., GOULART, M. and PETRUCIO, M. 2002. Aplicação de um protocolo de avaliação rápida da diversidade de habitats em atividades de ensino e pesquisa (MG-RJ). Acta Limnologica Brasiliensia, vol. 14, no. 1, p. 91-98.

CALOW, P. and PETTS, EGE. 1994. The Rivers Handbook. Hydrological and Ecological Principles. Oxford: Blackwell Science, vol. 2, $524 \mathrm{p}$

CORBI, JJ. and TRIVINHO-STRIXINO, S. 2006. Influence of taxonomic resolution of stream macroinvertebrate com- munities on the evaluation of different land uses. Acta Limnologica Brasiliensia, vol. 18, p. 469-475.

COSTA, C., IDE, S. and SIMONKA, CE. 2006. Insetos imaturos: metamorfose e identificação. Ribeirão Preto: Holos. 249 p.

CRIVELLI, AJ. 2002. The role of protected areas in freshwater fish conservation. In COLLARESPEREIRA, MJ., COWX, IG. and COELHO, MM., orgs. Conservation of Freshwater Fishes: Options for the Future. Paris: Fishing News Books. p. 373-388.

DUDLEY, N. and STOLTON, S. 2003. Running Pure: the Importance of Forest Protected Areas to Drinking Water. World Bank, WWF Alliance for Forest Conservation and Sustainable Use.

FERNANDEZ, HR. and DOMINGUES, EE. 2001. Guía para la determinación de los artropodos bentónicos Sudamericanos. Tucumán: UNT. 282 p.

FLOTEMERSCH, JE., STRIBLING, JB., HUGHES, RM., REYNOLDS, L., PAUL, MJ., and WOLTER, C. 2011. Site length for biological assessment of boatable rivers. River Research and Applications, vol. 27, no. 4, p. 520-535. http://dx.doi.org/10.1002/ rra. 1367

FRICOVÁ, K., RUZICKOVÁ, J. and HREBÍK, S. 2007. Benthic macroinvertebrates as indicators of ecological integrity of lotic ecosystems in the Šumava National Park, Czech Republic. Silva Gabreta, vol. 13, no. 1, p. 39-55.

GILLER, PS. and MALMQVIST, B. 2008. The biology of streams and rivers. New York: Oxford University Press.

GOTELLI, NJ. and ELLISON, AM. 2004. A primer of ecological statistics. Massachusetts: Sinauer Associates Inc. $510 \mathrm{p}$.

INSTITUTO BRASILEIRO DE ANÁLISES SOCIAIS E ECONÔMICAS - IBASE. 2006. Água: Bem público em Unidade de Conservação. In FRANCA, N., org. Rio de Janeiro: IBASE. 27 p.

KANNO, Y., VOKOUN, JC., DAUWALTER, DC., HUGHES, RM., HERLIHY, AT., MARET, TR. and PATTON, TM. 2009. Influence of rare species on electrofishing distance-species richness relationships at stream sites. Transactions of the American Fisheries 
Society, vol. 138, p. 1240-1251. http://dx.doi. org/10.1577/T08-210.1

KAY, WR., SMITH, MJ., PINDER, AM., McRAE, JM, DAVIS, JA. and HALSE, SA. 1999. Patterns of distribution of macroinvertebrate families in rivers of north-western Australia. Freshwater Biology, vol. 41, p. 299-316. http://dx.doi.org/10.1046/j.13652427.1999.00432.x

LAJEUNESSE, D., DOMON, G., DRAPEAU, P., COGLIASTRO, A. and BOUCHARD A. 1995. Development and application of an ecosystem management for protected natural areas. Environmental Management, vol. 19, p. 481-495. http://dx.doi.org/10.1007/BF02471962

LOGAN, P. and BROOKER, EMP. 1983. The macroinvertebrate faunas of riffles and pools. Water Research, vol. 17, no. 3, p. 263-270. http://dx.doi. org/10.1016/0043-1354(83)90179-3

MAGURRAN, AE. 2004. Measuring biological diversity. Oxford: Blackwell Publishing. 256 p.

MANCINI, L., FORMICHETTI, P., ANSELMO, A., TANCIONI, L., MARCHINI, S. and SORACE, A. 2005. Biological quality of running waters in protected areas: the influence of size and land use. Biodiversity and Conservation, vol. 14, p. 351-364. http://dx.doi.org/10.1007/s10531-004-5355-8

MANDAVILLE, SM. 2002. Benthic macroinvertebrates in freshwaters taxa tolerance values, metrics and protocols. Washington: EPA. 48 p.

MANEL S., BUCKTON ST. and ORMEROD SJ. 2000. Testing large-scale hypotheses using surveys: the effects of land use on the habitats, invertebrates and birds of Hymalayan rivers. Journal of Applied Ecology, vol. 37, p. 756-770. http://dx.doi.org/10.1046/ j.1365-2664.2000.00537.x

MASTER, LL., FLACK, SR. and STEIN, BA. 1998. Rivers of life: critical watersheds for protecting freshwater biodiversity. Virginia: The Nature Conservancy. 71 p.

McALLISTER, DE., HAMILTON, AL. and HARVEY, BH. 1997. Global freshwater biodiversity: striving for the integrity of freshwater ecosystems. Sea Wind, vol. 11, p. 1-140.

MEDEIROS, R., YOUNG, CEF., PAVESE, HB. and ARAÚJO, FFS. 2011. Contribuição das unidades de conservação brasileiras para a economia nacional. Brasília: UNEP-WCMC. 44 p.

MELO, AS. 2003. Diversidade de macroinvertebrados em riachos. In CULLEN JUNIOR, L., RUDRAN, R. and VALLADARES-PADUA, C., orgs. Métodos de estudos em biologia da conservação e manejo da vida silvestre. Curitiba: Editora da UFPR. p. 69-90.

MELO, AS. 2005. Effects of taxonomic and numeric resolution on the ability to detect ecological patterns at local scale using stream macroinvertebrates. Archiv für Hydrobiologie, vol. 164, no. 3, p. 309-323. http:// dx.doi.org/10.1127/0003-9136/2005/0164-0309

MERRITT, RW. and CUMMINS, KW. 1996. An introduction to the aquatic insects of North America. Dubuque: Kendal/Hunt, 862 p.
MILESI, SV., BIASI, C., RESTELLO, RM. and HEPP, LU. 2009. Distribution of benthic macroinvertebrates in Subtropical streams (Rio Grande do Sul, Brazil). Acta Limnologica Brasiliensia, vol. 21, no. 4, p. 419429.

MORETTI, MS., GONÇALVES, JF., LIGEIRO, R. and CALLISTO, M. 2007. Invertebrates colonization on native trees leaves in a Neotropical stream (Brazil). International Review of Hydrobiology, vol. 92, no. 2, p. 199-210. http://dx.doi.org/10.1002/ iroh.200510957

MOULTON, T. and SOUZA, ML. 2006. Conservação com Base em Bacias Hidrográficas. In ROCHA, CFD., BERGALLO, HG., SLUYS, MV. and ALVES, MAS., orgs. Essências em Biologia da Conservação. Porto Alegre: RiMa. 582 p.

MOYLE, PB. and YOSHIYAMA, RM. 1994. Protection of aquatic biodiversity in California: a five-tiered approach. Fisheries, vol. 19, p. 6-18. http://dx.doi. org/10.1577/1548-8446(1994)019<0006:POABI $\mathrm{C}>2.0 . \mathrm{CO} ; 2$

MUOTKA, T., PAAVOLA, R., HAAPALA, A., NOVIKMEC, M. and LAASONEN, P. 2002. Longterm recovery of stream habitat structure and benthic invertebrate communities from in-stream restoration. Biological Conservation, vol. 105, p. 243-253. http:// dx.doi.org/10.1016/S0006-3207(01)00202-6

NAIMAN, RJ., DECAMPS, H. and POLLOCK, M. 1993. The role of riparian corridors in maintaining regional biodiversity. Ecological Applications, vol. 3, p. 209-212. http://dx.doi.org/10.2307/1941822

NEILL, C., DEEGAN, LA., THOMAS, SM. and CERRI, CC. 2001. Deforestation for pasture alters nitrogen and phosphorus in small Amazonian streams. Ecological Applications, vol. 11, p. 1817-1828. http:// dx.doi.org/10.1890/1051-0761(2001)011[1817:DF PANA]2.0.CO;2

PAZ, A., MORENO, P., ROCHA, L. and CALLISTO, M. 2008. Efetividade de áreas protegidas (APs) na conservação da qualidade das águas e biodiversidade aquática em sub-bacias de referência no rio das Velhas (MG). Neotropical Biology and Conservation, vol. 3, p. 149-158. http://dx.doi.org/10.4013/ nbc.20083.06

PEREIRA, D. and LUCA, J. 2003. Benthic macroinvertebrates and the quality of the hydric resources in Maratá Creek basin (Rio Grande do Sul, Brazil). Acta Limnologica Brasiliensia, vol. 15, no. 2, p. 57-68.

PEREIRA-SILVA, EFL., HARDT, E., DOS SANTOS, JE., PIRES, JSR, and FERREIRA, WA. 2011. Avaliação da qualidade da água em microbacias hidrográficas de uma Unidade de Conservação do Nordeste do estado de São Paulo, Brasil. Brazilian Journal of Biosciences, vol. 9, no. 3, p. 371-381.

PLAFKIN, JL., BABOUR, MT., PORTER, KD., GROSS, SK. and HUGHES, RM. 1989. Rapid Bioassesment Protocols for Use in Streams and Rivers: Benthic Macroinvertebrate and Fish. Washington: 
Environmental Protection Agency (EPA). EPA444/4-89-001.

R DEVELOPMENT CORE TEAM. 2009. $R: A$ language and environment for statistical computing. Vienna: R Foundation for Statistical Computing.

RAMPAZZO, SE., SANTOS JE., PIRES, JSR., HENKEOLIVEIRA, C., RIGO, CP. and MOSCHINI, LE. 2000. Caracterização ambiental da unidade de conservação da região Alto Uruguai - Marcelino Ramos (RS). In Fórum de Debates: Ecologia da Paisagem e Planejamento Ambiental. Rio Claro: Sociedade de Ecologia do Brasil.

RESH, VH. 1995. Freshwater benthic macroinvertebrates and rapid assessment procedures for water quality monitoring in developing and newly industrialized countries. In DAVIS, WS. and SIMON, TP., orgs. Biological assessment and criteria: tools for water resource planning and decision making. Boca Raton: Lewis Publishers, p. 195-233.

RESTELLO, RM. and PENTEADO-DIAS, AM. 2006. Diversidade dos Braconidae (Hymenoptera) da Unidade de Conservação de Teixeira Soares, Marcelino Ramos, RS, com ênfase nos Microgastrinae. Revista Brasileira de Entomologia, vol. 50, no. 1, p. 80-84.

RICHTER, BD., BRAUN, DP., MENDELSON, MA., and MASTER, LL. 1997. Threats to imperiled freshwater fauna. Conservation Biology, vol. 11, p. 1081-1093. http://dx.doi.org/10.1046/j.15231739.1997.96236.x

ROSENBERG, DM. and RESH, VH. 1993. Introduction to freshwater biomonitoring and benthic macroinvertebrates. In ROSENBERG, DM. and RESH, VH., orgs. Freshwater biomonitoring and benthic macroinvertebrates. New York: Chapman and Hall. p. 1-9.

ROUX, DJ., NEL, JL., ASHTON, PJ., DEACON, AR., DE MOOR, FC., HARDWICK, D., HILL, L., KLEYNHANS, CJ., MAREE, GA., MOOLMAN, J. and SCHOLES, RJ. 2008. Designing protected areas to conserve riverine biodiversity: Lessons from a hypothetical redesign of the Kruger National Park. Biological Conservation, vol. 141, p. 100-117. http:// dx.doi.org/10.1016/j.biocon.2007.09.002

SAUNDERS, DL, MEEUWIG, JJ. and VINCENT, ACJ. 2002. Freshwater Protected Areas: Strategies for Conservation. Conservation Biology, vol. 16, no. 1, p. 30-41. http://dx.doi.org/10.1046/j.15231739.2002.99562.x

SILVEIRA, MP. 2004. Aplicação do biomonitoramento para avaliação da qualidade da água em rios. Jaguariúna: Embrapa Meio Ambiente. 68 p.

SILVEIRA, MP., BAPTISTA, DF., BUSS, DF., NESSIMIAN, JL. and EGLER, M. 2005. Application of biological measures for stream integrity assessment in south-east Brazil. Environmental Monitoring \& Assessment, vol. 101, no. 1-3, p. 117-128. PMid:15736880.

SKELTON, PH. 2002. An overview of the challenges of conserving freshwater fishes in South Africa. In COLLARES-PEREIRA, MJ., COWX, IG. and COELHO, MM., orgs. Conservation of Freshwater Fishes: Options for the Future. Paris: Fishing News Books, p. 221-236.

SOCIOAMBIENTAL. 2001. Plano de Manejo do Parque Natural Municipal Teixeira Soares/RS. Florianópolis: Socioambiental Consultores Associados. 124 p.

STENERT, C., SANTOS, EM., OLIVA, TD. and MALTCHIK, L. 2002. Diversidade de macroinvertebrados em áreas úmidas na Bacia do Rio dos Sinos, RS, Brasil. Acta Biologica Leopoldensia, vol. 24, no. 2, p. 157-172.

THIEME, ML., RUDULPH, J., HIGGINS, J., and TAKATS, JA. 2012. Protected areas and freshwater conservation: a survey of protected area managers in the Tennessee and Cumberland River Basins, USA. Journal of Environmental Management, vol. 109, p. 189-199. PMid:22819600. http://dx.doi. org/10.1016/j.jenvman.2012.06.021

TREVISAN, A. and HEPP, LH. 2007. Chemistry compound dynamic of leaf-litter and fauna associated with breakdown process of arboreous species in a stream from North of Rio Grande do Sul, Brazil. Neotropical Biology and Conservation, vol. 2, no. 1, p. 54-60.

TROUT UNLIMITED. 1993. Trout unlimited lawsuit gains environmental review of California fish hatcheries. Vienna: Press Release.

VANNOTTE, RL., MINSHALL, GW., CUMMINS, KW., SEDELL, JR. and CUSHING, CF. 1980. The River Continuum Concept. Canadian Journal of Fisheries and Aquatic Sciences, vol. 37, p. 817-822.

WALSH, CJ., SHARPE AK., BREEN PF. and SONNEMAN JA. 2001. Effects of urbanization on streams of the Melbourne region, Victoria, Australia. Freshwater Biology, vol. 46, p. 535-551. http://dx.doi. org/10.1046/j.1365-2427.2001.00690.x

WHITE, PS. and BRATTON, SP. 1980. After preservation: philosophical and practical problems of change. Biological Conservation, vol. 18 p. 241-245. http://dx.doi.org/10.1016/0006-3207(80)90001-4

WORLD CONSERVATION UNION - IUCN. 1999. Activities and partners in water resource management. Wetlands and water resources programme. Switzerland: Gland.

YOUNG, M. 1997. Sixty years of conservation. April: Ducks Unlimited March. p. 42-57. 